\title{
ТІМЕА КУЛЧАР
}

старший викладач кафедри історії Угорщини та європейської інтеграції

Ужгородського національного університету, аспірант Дебреценського університету м. Ужгород, Україна e-mail: matea2007@freemail.hu

\section{УГОРСЬКИЙ ДОСВІД РОЗВИТКУ ЄВРО-РЕГІОНАЛЬНОГО ТРАНСКОРДОННОГО СПІВРОБІТНИЦТВА}

Статтю присвячено досвіду Угорщини у розвитку євро-регіонального транскордонного співробітництва. Особлива увага була приділена динаміки розбудови угорського євро-регіону Західна Паннонія. В ході дослідження ставиться акцент на ініціативи Східного партнерства.

Ключові слова: Угорщина, Україна, Європа, співпраця, євро-регіон, транскордонне співробітництво.

Вагомою подією у розвитку українськоугорського транскордонного співробітництва після 2004 р., вважається східне розширення Європейського Союзу, тобто по-перше, формуванням нового східного кордону ЄС 3 Україною і по-друге, приєднанням Угорщини (відповідно і її регіонів) до ЄС. Насамперед потрібно відзначити, що на думку визначного угорського вченого Т. Гарді, внаслідок вступу Угорщини в ЄС iї східні кордони «зустрічаються» 3 соціально-економічними депресивними територіями, тобто «периферія зустрічається з периферією» [3].

У зв'язку із розташуванням вздовж кордонів Євросоюзу східних прикордонних територій країн Центральної Європи помічається занижений соціально-економічний розвиток ïx, що призводить до формування нової геоекономічної та геополітичної ситуації, що i дозволяє класифікувати цей випадок, за Й. Рехнітцером, як «подвійну периферію [13; 9-72, 73-127].

Вітчизняна історична наука лише опосередковано займається питаннями розвитку євро-регіонів, зокрема в контексті досліджень міжрегіональних зв'язків країн Вишеградської четвірки (наукові роботи Є.Б. Кіш) [2], транскордонної співпраці (публікації М. О. Лендьєл) [3], питань безпеки (публікації C. І. Мітряєвої) [5]. Більш конкретно, теоретично і практично, вивчають євро-регіони економісти: А. В. Балян [1], Н. Мікула [4], Ю. М. Шолох [7]. Угорська наукова школа вивчення євро-регіонального досвіду презентована перш за все науковими роботами Тамаша Гарді [8], Ласло Данч [10], Дюли Горват
[9], Жужанни Людвіг [11], Яноша Рехнітцера [12, 13], Шюлі Заккара [15].

Метою наукового аналізу є дослідження теоретичних підвалин формування та розвитку угорських євро-регіонів.

Актуальність питання визначається максимальною адаптацією прикордонних українських регіонів до європейських норм транскордонного співробітництва у тісній практичній взаємодії з угорськими прикордонними регіонами, які вже активно діють у правовому полі європейської регіональної політики. Важливою $є$ також і адаптація європейського, угорського досвіду транскордонної співпраці в Україні.

3 часу підписання Мадридської Конвенції, Угорщина по всьому периметру кордонів сформувала євро-регіони: євро-регіон Земплен; Карпатський Євро-регіон; Кошіце-Мішкольц Євро-регіон; Шайо-Ріма Євро-регіон; Neogradiensis Євро-регіон; Іполь Євро-регіон; ВагДунай-Іполь Євро-регіон; Ister-Granum Єврорегіон; Дунай-Кереш-Марош-Тиса Єврорегіoн; West/Західна Паннонія Євро-регіон; Дунай-Драва-Сава Євро-регіон; Трикордоння Дуная Євро-регіон; Драва-Мура Євро-регіон; Гайду Бігар-Бігор Євро-регіон; Бігар-Бігор Євро-регіон. Хвиля інституційного оформлення співпраці прикордонних регіонів Угорщини 3 регіонами Європи в формі євро-регіонів у подальшому перейшла у русло якісної розбудови співпраці на транскордонному рівні. За розміром, територіальним розташуванням i зв'язками євро-регіони Угорщини можна поділити на два типи. Перший тип - це велика євро-регіональна модель (зокрема, це 
Карпатський євро-регіон), і друга - мала більш ефективніша євро-регіональна модель, в більшій мірі двостороннього характеру із домінуванням співпраці саме прикордонних міст [12]. I не слід забувати, що євро-регіони Угорщини, створені наприклад, на угорськоавстрійському кордоні, суттєво відрізнялися i нині на жаль відрізняються від угорськоукраїнського включно Карпатського єврорегіону.

Зрозуміло, що метою євро-регіонів Угорщини було досягнення якісно високого рівня у співпраці. Як цілком справедливо зазначає Д. Скотт «швидкий інституційний розвиток транскордонного співробітництва забезпечує політичну безпеку і долучається до нових європейських територіальних вимірів» [14]. Визначаються європейські територіальні виміри, де існує розгалужена широка мережа суспільних і культурних зв'язків, існує швидка і розгалужена комунікація, конкурентоспроможна економіка, де зменшується роль і значення периферії, і що найважливіше багатоетнічне населення в цих прикордонних регіонах живе без конфліктів та у взаємоповазі.

Євро-регіони Угорщини на стадії формування, намагались якомога ефективніше адаптувати конкретну західноєвропейську модель євро-регіону. I що цікаво, у порівнянні із західноєвропейськими регіонами, цей процес відбувався пришвидшено, де євро-регіони проходили перевірку часом.

Західний вимір євро-регіонів, за участю прикордонних регіонів Угорщини, фактично був спрямований на поступову європейську інтеграцію країни, ще до набуття Угорщиною повноправного членства в Євросоюзі. 3поміж євро-регіонів західного прикордоння Угорщини, на нашу думку, вважаємо за доцільне проаналізувати діяльність австрійськоугорського євро-регіону West/Західна Паннонія. Євро-регіон West/Західна Паннонія було створено у 1998 році з метою вирішення проблемних питань транскордонного характеру. Хоча, зазначимо, що досвід співпраці прикордонних регіонів Австрії (східна федеральна земля Австрії - Бургенланд) та Угорщини (область Дьєр-Мошон-Шопрон та Ваш).

Євро-регіон Західна Паннонія був створений на тоді ще східному кордоні ЄС, отже дос- від євро-регіональної співпраці набутий західними прикордонними регіонами Угорщини представляє значний інтерес для України. Характерними особливостями цього єврорегіону є мультикультуралізм, роль своєрідного мосту, який з'єднував Захід і Схід у 1990-х роках, досить високий соціальноекономічний рівень розвитку прикордонних територій порівняно зі східними регіонами Угорщини, формування центру динамічного розвитку торгово-економічних зв'язків, відсутність проблем в історичній пам'яті жителів прикордонних регіонів, доволі високий рівень проникливості кордону навіть у 1980-90-х роках.

Зважаючи на географічне розташування євро-регіону Західна Паннонія, цей єврорегіон слугував моделлю співпраці прикордонних регіонів $Є С$ та не членів ЄС. Необхідно також відмітити питання фінансування спільних транскордонних проектів. Після вступу Австрії в ЄС, протягом 1995-1999 років в рамках Програми PHARE з транскордонного співробітництва між Угорщиною та Австрією було використано 42 мільйонів євро з метою реалізації проектів з територіального планування та розвитку, розвитку технічної інфраструктури, економічної кооперації, людських ресурсів, захисту навколишнього середовища, підтримки так званих малих проектів. Організаційна структура євро-регіону Західна Паннонія була створена на взірець моделі інституцій євро-регіону Нейсе-Ніса-Ниса. Утім, були враховані як регіональні особливості, так і досвід співробітництва єврорегіонів Польщі.

В інституційному значенні важливим було створення Транскордонної Регіональної Ради у 1992 році. У 1999 році до євро-регіону приєдналася і область Зала, отже єврорегіон об'єднує три угорських і один австрійський регіони. Рада Євро-регіону складається 3 40 делегованих представників чотирьох прикордонних регіонів - партнерів. Президія $\epsilon$ найвищою політичною інституцією, серед її основних завдань: розробка стратегій розвитку євро-регіону Західна Паннонія та визначення коротко та середньострокових цілей розвитку. Конкретна робота здійснюється в рамках 8 робочих комісій. Кожна з областей 
має власний секретаріат і координує діяльність двох робочих груп. У 2002 році було розроблено Стратегічний документ розвитку єврорегіону Західна Паннонія.

Приєднання Угорщини до ЄС відповідно функціонально поступово змінює євро-регіон Західну Паннонія, тобто змінюються плани територіального розвитку євро-регіону. 3 точки зору економічного розвитку прикордонних територій, для усього євро-регіону i раніше характерною особливістю був як високий, динамічний розвиток економіки, так i активність економічних зв' язків. Вигідне геополітичне та геоекономічне розташування у вимірі Схід-Захід, перетин тут міжнародних автомагістралей і швидкісних європейських залізничних сполучень, зокрема це Відень Будапешт, Венеція - Трієст - Будапешт, наявність логістичних центрів: Дер-Гене, Шопрон, Надьканіжа, і що особливо важливо - висококваліфікованої робочої сили (560.000 осіб), 42.000 підприємств євро-регіону Західної Паннонії в цілому створило сприятливі умови для заснування і розвитку на території євро-регіону Автомобільного Кластеру Паннонія та Гелігенкреус- Сентгортхард транскордонного промислового парку [1].

Особливої уваги заслуговує ініціатива Східного партнерства, котру в травні 2008 року пропонували Польща та Швеція, які пропагували поглиблення взаємин зі східними сусідами, охопленими Європейською політикою сусідства, включно з Україною. Перша зустріч Східного Партнерства на найвищому рівні відбулася 7 травня 2009 року у Празі. Це стало офіційним початком вказаної ініціативи, на якому було ухвалено Спільну Декларацію та підсумовано успішні зусилля щодо встановлення ініціативи як невід'ємної частини політики Європейського Союзу. Східне партнерство по суті, $\epsilon$ продовженням політики сусідства, тобто це означає, що наразі не передбачається входження країн - його учасників до ЄС.

Серед офіційних положень Комунікації Східного партнерства можливо відмітити: створення поглиблених зон вільної торгівлі; лібералізацію візового режиму між $€$ та країнами-партнерами $з$ можливістю започаткування безвізового діалогу з ними за умови попередньої «ефективної імплементації» угод про спрощення оформлення віз та реадмісію осіб; запровадження багатостороннього політичного діалогу між $Є С$ та країнамипартнерами в рамках Саміту (раз на 2 роки), зустрічей на рівні міністрів закордонних справ (щорічно) та в рамках чотирьох тематичних платформ; створення спеціальної програми допомоги для зміцнення адміністративної спроможності країн-партнерів; зміцнення енергетичної безпеки $Є C$ та його партнерів на принципах Енергетичної Хартії; вирівнювання регіонального розвитку країнпартнерів; оновлення договірно-правової бази відносин ЄС зі східними сусідами через заміну чинних угод про партнерство та співробітництво на посилені угоди нового формату [6].

Важливість саме поступової розбудови євро-регіонів, застосування методу крок за кроком у інституційній розбудові єврорегіону підкреслює Д.Скотт. Дослідник Д.Скотт даючи аналіз сучасній діяльності та досвіду розвитку євро-регіонів на голландсько-німецькому прикордонні, зазначив спільні риси та характеристики системного розвитку:

- протягом довгих років ЄС та НАТО спонукало прикордонні регіони до міжнародної співпраці;

- в економіці прикордонних регіонів наявними $€$ подібні структурні проблеми «периферійності» (проблеми із працевлаштуванням, реструктуризація економіки, односторонній розвиток сфер діяльності, нерозвиненість сфери послуг, віддалене розташування від економічних центрів);

- спільність національних інтересів, які мають в більшій мірі економічний та культурний виміри, ніж безпековополітичний;

- між голландськими провінціями та німецькими землями не існує суттєвих відмінностей, вони мають подібну політичну та фінансову автономію;

- формування широкої розгалуженої мережі економічних, суспільних та культурних зв'язків і пошук в них пріоритетів розвитку

- у економічній, суспільній та політичній інституційній системах мало асиметрії, втім є багато спільних екологічних та соціальних проблем [14]. 
На нашу думку запропонована методика, iï імплікація на прикордонні Угорщини та України виходячи власне із внутрішніх характеристик, багато в чому є відмінною, які на жаль $є$ суттєво відмінними навіть на рівні двох периферійних прикордонних регіонів на новому східному кордоні ЄС та України. Звичайно спільних негативних складових на прикордонні Угорщини та України можна і надалі розширити, низький соціальноекономічний рівень розвитку, застаріла ін- фраструктура, низький рівень освіти, як недостатність фінансування тощо. Отже, розвиток євро-регіонів України необхідно розвивати і підтримувати. Вагомим, навіть принципово суттєвим визначаємо важливість на українсько-угорському прикордонні реалізації європейських принципів у розбудові євро-регіонів, а саме, принципу субсидіарності, децентралізації та розробки стратегічного плану розвитку прикордонних територій.

\section{Список використаних джерел}

1. Балян А.В. Міжрегіональне, транскордонне співробітництво України за умов розширення Європейського Союзу (на прикладі прикордонних регіонів України та Угорщини). Ужгород: Ліра, 2005. 320 с.

2. Кіш Є. Центральна Європа в сучасній системі єврорегіональної інтеграції. Ужгород: Ліра, 2008. 440 с.

3. Лендьєл М. Досвід Карпатського Єврорегіону: поштовх до переосмислення моделі транскордонного співробітництва // На шляху до Європи. Український досвід єврорегіонів. К.: Логос, 2000. 224 с.

4. Мікула Н. А. Єврорегіони: досвід та перспективи. Львів: ІРД НАН України, 2003. 222 с.

5. Мітряєва С. І. Карпатський єврорегіон - інструмент єврорегіональної стратегії України // Стратегічна панорама. 2005. №1. C. 42-51.

6. Східне партнерство. [SEC(2008) 2974] // Режим доступу: http://www.kmu.gov.ua/kmu/control/uk/publish/

7. Шолох Ю.М. Стратегічне планування розвитку прикордонного регіону (на прикладі Закарпатської області) // Регіональна економіка. 2007. № 2. С. 131-138.

8. Hardi T. Államhatárok és regionális együttműködések // Magyarország területi szerkezete és folyamatai az ezredfordulón (szerk.: Horváth Gy., Rechnitzer J.) / T.Hardi. Pécs: MTA RKK, 2000. 595-615 old.

9. Horvát Gy. Európai regionális politika. Dialóg Campus. Bp-Pécs, 1998. 501 old.

10. Dancs L. A határforgalom és a határmenti lakossági kapcsolatok jellegzetességei a magyar-ukrán határ mentén a rendszerváltástól az uniós csatlakozásig // A határmenti együttműködés lehetőségei és korlátai Magyarország és Ukrajna között. Nyiregyháza-Ungvár, 2004. P. 74-83.

11. Ludvig Zsuzsa. Süli-Zakar István. Együttműködés és felzárkózás a Kárpátok Eurorégióban. Budapest: Stádium, 2002.139 old.

12. Rechnitzer J. Eurorégió vázlatok a magyar-osztrák-szlovák határ menti térségben // Tér és Társadalom. 1997. № 2. 29-54 old.

13. Rechnitzer J. Határ menti együttmúködések Európában és Magyarországon. Az osztrák-magyar határ menti együttműködés a kilencvenes években // Elválaszt és összeköt - a határ (szerk.: Nárai M., Rechnitzer J.). Pécs-Győr: MTA Regionális Kutatások Központja, 1999. 9-72 old.

14. Scott J. A határ menti együttműködés nemzetközi rendszerei, Németország, Lengyelország és az EU // Tér és Társadalom. 1997. № 3-4. 117-142 old.

15. Süli-Zakar István. A Kárpátok Eurorégió interregionális szövetség tíz éve. Debrecen, 2003. 357 old.

\section{References}

1. Baljan A.V. Mizhreghionaljne, transkordonne spivrobitnyctvo Ukrajiny za umov rozshyrennja Jevropejsjkogho Sojuzu (na prykladi prykordonnykh reghioniv Ukrajiny ta Ughorshhyny). Uzhghorod: Lira, 2005. 320 c.

2. Kish Je. Centraljna Jevropa v suchasnij systemi jevroreghionaljnoji integhraciji. Uzhghorod: Lira, 2008. $440 \mathrm{~s}$.

3. Lendjjel M. Dosvid Karpatsjkogho Jevroreghionu: poshtovkh do pereosmyslennja modeli transkordonnogho spivrobitnyctva // Na shljakhu do Jevropy. Ukrajinsjkyj dosvid jevroreghioniv. K.: Loghos, 2000. 224 s.

4. Mikula N.A. Jevroreghiony: dosvid ta perspektyvy. Ljviv: IRD NAN Ukrajiny, 2003. $222 \mathrm{s.}$

5. Mitrjajeva S.I. Karpatsjkyj jevroreghion - instrument jevroreghionaljnoji strateghiji Ukrajiny // Strateghichna panorama. 2005. №1. S. 42-51.

6. Skhidne partnerstvo. [SEC(2008) 2974] // Rezhym dostupu: http://www.kmu.gov.ua/kmu/control/uk/publish/

7. Sholokh Ju.M. Strateghichne planuvannja rozvytku prykordonnogho reghionu (na prykladi Zakarpatsjkoji oblasti) // Reghionaljna ekonomika. 2007. № 2. S. 131-138.

8. Hardi T. Államhatárok és regionális együttműködések // Magyarország területi szerkezete és folyamatai az ezredfordulón (szerk.: Horváth Gy., Rechnitzer J.). Pécs: MTA RKK, 2000. 595-615 s.

9. Horvát Gy. Európai regionális politika. Dialóg Campus. Bp-Pécs, 1998. $501 \mathrm{~s} \mathrm{.}$

10. Dancs L. A határforgalom és a határmenti lakossági kapcsolatok jellegzetességei a magyar-ukrán határ mentén a rendszerváltástól az uniós csatlakozásig // A határmenti együttműködés lehetőségei és korlátai Magyarország és Ukrajna között. Nyiregyháza-Ungvár, 2004. P. 74-83.

11. Ludvig Zsuzsa. Süli-Zakar István. Együttműködés és felzárkózás a Kárpátok Eurorégióban. Budapest: Stádium, 2002.139 s.

12. Rechnitzer J. Eurorégió vázlatok a magyar-osztrák-szlovák határ menti térségben // Tér és Társadalom. 1997. № 2. S. 29-54.

13. Rechnitzer J. Határ menti együttmúködések Európában és Magyarországon. Az osztrák-magyar határ menti együttműködés a kilencvenes években // Elválaszt és összeköt - a határ (szerk.: Nárai M., Rechnitzer J.). Pécs-Győr: MTA Regionális Kutatások Központja, 1999. S. 9-72.

14. Scott J. A határ menti együttműködés nemzetközi rendszerei, Németország, Lengyelország és az EU // Tér és Társadalom. 1997. № 3-4. s. 117-142.

15. Süli-Zakar István. A Kárpátok Eurorégió interregionális szövetség tíz éve. Debrecen, 2003. 357 s. 


\section{Тимея Кулчар. Венгерский опыт развития евро-регионального трансграничного сотруд- ничества}

Статья посвящена опыту Венгрии в развитии евро-регионального трансграничного сотрудничества. Особое внимание было уделено динамики развития венгерского евро-региона Западная Паннония. В ходе исследования ставится акцент на инициативе Восточного партнерства.

Ключевые слова: Венгрия, Украина, Европа, сотрудничество, еврорегион, трансграничное сотрудничество.

\section{Timea Kulchar. Hungarian experience in the development of euro-regional cross-border co- operation}

The article is devoted to the experience of Hungary in the development of Euro-regional cross-border cooperation. It is clear that the aim of the Euro-regions of Hungary was to achieve a high level of cooperation. These are European territorial dimensions, where there is rapid and branched communication, a competitive economy, where the role and importance of the periphery are diminished, there is an extensive network of social and cultural ties, and that the multiethnic population in these border regions is particularly important. without conflict. At the formation stage, the Hungarian Euro-regions sought to adapt as effectively as possible the specific Western European model of the Euro-region. Interestingly, this was done very quickly compared to the Western European regions where the euro-regions were subject to time-checks. Particular attention was paid to the dynamics of the development of the Hungarian Euro-region of Western Pannonia. The Western Pannonia Euro-region was created on the then-eastern border of the EU, so the experience of Euro-regional cooperation gained by Hungary's western border regions is of considerable interest to Ukraine. Hungary's accession to the EU is functionally gradually changing the Euro-region of Western Pannonia, that is, changing the territorial development plans of the Euro-region. Given the geographical location of the Western Pannonia Euro-region, this Euro-region served as a model for cooperation between $E U$ and non-EU border regions. It should also be noted that funding for joint cross-border projects is important. From the point of view of economic development of the border areas, the high, dynamic development of the economy and the activity of economic ties were still characteristic of the whole Euro-region. The study focuses on the Eastern Partnership initiative. Particularly noteworthy is the Eastern Partnership initiative put forward in May 2008 by Poland and Sweden, which proposed a deepening of relations with eastern neighbors covered by the European Neighborhood Policy, including Ukraine. The Eastern Partnership is, in essence, a continuation of the Neighborhood Policy, ie it means that no EU member states are currently expected to enter.

Key words: Hungary, Ukraine, Europe, cooperation, Euro-region, cross-border cooperation. 